\title{
Distribution of Archaeal and Bacterial communities in a subtropical reservoir
}

Distribuição das comunidades de Arquéias e Bactérias em um reservatório subtropical.

Laís Américo Soares ${ }^{1}$, André Cordeiro Alves Dos Santos², Iolanda Cristina Silveira Duarte², Emiliana Manesco Romagnoli ${ }^{3}$ and Maria do Carmo Calijuri ${ }^{4}$

${ }^{1}$ Departamento de Hidráulica e Saneamento, Escola de Engenharia de São Carlos, Universidade de São Paulo - USP, Avenida João Dagnone, 1100, CEP 13563-120, São Carlos, SP, Brazil e-mail: americo.lais@gmail.com

${ }^{2}$ Departamento de Biologia, Centro de Ciências Humanas e Biológicas, Universidade Federal de São Carlos - UFSCar, Rodovia João Leme dos Santos, Bairro do Itinga, CEP 18052-780, Sorocaba, SP, Brazil e-mail andrecas@ufscar.br; iolanda@ufscar.br

${ }^{3}$ Departamento de Microbiologia Agrícola, Escola Superior de Agricultura Luiz de Queiroz - ESALQ, Universidade de São Paulo - USP, Av. Pádua Dias, 11, CEP 13418-900, Piracicaba, SP, Brazil e-mail: emilianaromagnoli@usp.br

${ }^{4}$ Departamento de Hidráulica e Saneamento, Escola de Engenharia de São Carlos, Universidade de São Paulo - USP, Av. Tabalhador São Carlense, 400, CEP 13566-590, São Carlos, SP, Brazil e-mail: Calijuri@sc.usp.br

\begin{abstract}
Aim: Microbial communities play a central role in environmental process such as organic matter mineralization and the nutrient cycling process in aquatic ecosystems. Despite their ecological importance, variability of the structure of archaeal and bacterial communities in freshwater remains understudied. Methods: In the present study we investigated the richness and density of archaea and bacteria in the water column and sediments of the Itupararanga Reservoir. We also evaluated the relationship between the communities and the biotic and abiotic characteristics. Samples were taken at five depths in the water column next to the dam and three depths next to the reservoir entrance. Results: PCR-DGGE evaluation of the archaeal and bacterial communities showed that both were present in the water column, even in oxygenated conditions. Conclusions: The density of the bacteria (qPCR) was greater than that of the archaea, a result of the higher metabolic plasticity of bacteria compared with archaea.
\end{abstract}

Keywords: freshwater; microbial communities; PCR/DGGE; real time PCR.

Resumo: Objetivo: As comunidades microbianas desempenham papel crucial nos processos ambientais como na mineralização de matéria orgânica e ciclagem de nutrientes em ambientes aquáticos. No entanto, apesar da importância ecológica de archaea e bactéria em ambientes aquáticos, a estrutura destas comunidades permanece pouco estudada. Métodos: Neste sentido, nos avaliamos a riqueza e densidade de archaea e bactéria na coluna d'água e no sedimento do reservatório de Itupararanga e avaliamos as relaçóes entre os fatores bióticos e abióticos. Para tanto, amostragens foram realizadas em cinco profundidades na região próxima a barragem e em três profundidades no ponto da entrada. Resultados: A partir de PCR-DGGE observou-se que ambas as comunidades distribuíram-se ao logo dos pontos de amostragem, mesmo em condições com presença de oxigênio. Conclusóes: A densidade bacterianas, avaliada por qPCR foi maior do que a de archaea, provavelmente devido a maior plasticidade metabólica desses microrganismos.

Palavras-chave: águas continentais; comunidade microbiana; PCR/DGGE; real time PCR. 


\section{Introduction}

Prokaryote microorganisms play an important role in aquatic metabolism, especially in tropical environments (Sarmento, 2012). Despite the fact that microorganisms are the most abundant and diverse group in aquatic ecosystems, their physiology, diversity and trophic role are underestimated (Gasc et al., 2015).

Knowledge of the importance of archaea to aquatic metabolism, for example, is incipient, mainly due to the difficulty in cultivating this microorganism in laboratories (Llirós et al., 2014) and the usual association of archaea with extreme environments, which delayed the search for these microorganisms in many aquatic ecosystems, despite the fact that they are very abundant in some environments, such as the deep ocean (Dolan, 2005).

However, the microorganisms are essential in the organic decomposition processes, planktonic food chain and nutrient cycling, such as nitrogen and carbon cycle. In this sense, recent advances in biomolecular tools have enabled studies of the diversity, composition and abundance of these microorganisms in aquatics environments (Ferrera et al., 2015; Grossart, 2010; Williams \& Cavicchioli, 2014) to be undertaken.

Molecular biological methods based on the $16 S$ rDNA gene have improved our understanding of microbial diversity in different environments, including reservoirs. Archaeal communities have been found in sediments and in the anoxic zone of the water column (depth of $40 \mathrm{~m}$ ) in the Tucuruí Reservoir (Graças et al., 2011). Archaea has also been found in seawater (Cardoso et al., 2011; Cury et al., 2011; Francis et al., 2005), marine sediments (Bowman \& McCuaig, 2003; Nakayama et al., 2011), wetlands (Sims et al., 2012) and in association with other organisms, such as sponges (Turque et al., 2010).

While the bacterial community has been studied in aquatic ecology for longer, its diversity was not well known until the advent of molecular biological methods which enabled a new understanding of these organisms in the environment (Ferrera et al., 2015; Zeglin, 2015).

Environmental changes can modify the composition and diversity of microbial communities, as well as other aquatic communities, changing metabolic routes and consequently the structure of food chains and energy flow (Oleynik et al., 2011).

Changes in planktonic structure can influence other communities linked by the microbial loop.
This is the production and transfer of energy and matter between several groups, such as bacteria, archaea, viruses, protozoa and fungi (Thompson et al., 2011).

Eutrophication in reservoirs and lakes, such as increased organic matter and nutrients, can also alter the structure of the microbial community, which may lead to water pollution and changes in ecosystems (Adamczuk et al., 2015).

In the nitrogen cycle, for example, it is important to understand eutrophication. The role of Archaea and its relationship with the bacteria and ammonia metabolism has only recently been understood (Liu et al., 2011).

In this context, we evaluated the spatial distribution of Bacteria and Archaea and the chemical water proprieties of a subtropical reservoir (Itupararanga Reservoir, state of São Paulo, Brazil) in order to understand the ecological role of these communities.

\section{Material and Methods}

The study area is in the Itupararanga Reservoir in the state of São Paulo in southeastern Brazil. The reservoir receives water from the Sorocamirim, Sorocabuçu and Una Rivers, and provides water to eight cities with treated water and receives untreated sewage (Beghelli et al., 2014).

The trophic level of the Itupararanga Reservoir was classified as mesotrophic during the rainy season and eutrophic during the dry season (Cunha \& Calijuri, 2011a; Pedrazzi et al., 2013).

\subsection{Water and sediment samples and chemical analysis}

Two sites in the reservoir (Figure 1) were selected for chemical and biological sampling. Samples were taken at five depths $(0.0,2.0,4.0,10.0$ and $15.5 \mathrm{~m})$ near the dam, and three depths $(0.0,4.0$ and $8.0 \mathrm{~m})$ next to the reservoir entrance (river's inflow) (Table 1) during the rainy season (April, 2012).

Water samples (1 L) were taken with a Van Dorn water sampler and stored in sterile plastic bottles that were immediately taken to the lab, where they were stored at $4^{\circ} \mathrm{C}$ until analysis. Water quality measures $(\mathrm{pH}$, temperature and dissolved oxygen) were recorded at the sampling sites using an YSI multiparameter probe (potentiometric methods (Eaton et al., 2005). The concentration of ammonia ions, nitrate, nitrite, phosphorus, total Kjeldahl nitrogen, orthophosphate, alkalinity, and organic and inorganic solids were analyzed according to Eaton et al. (2005). 


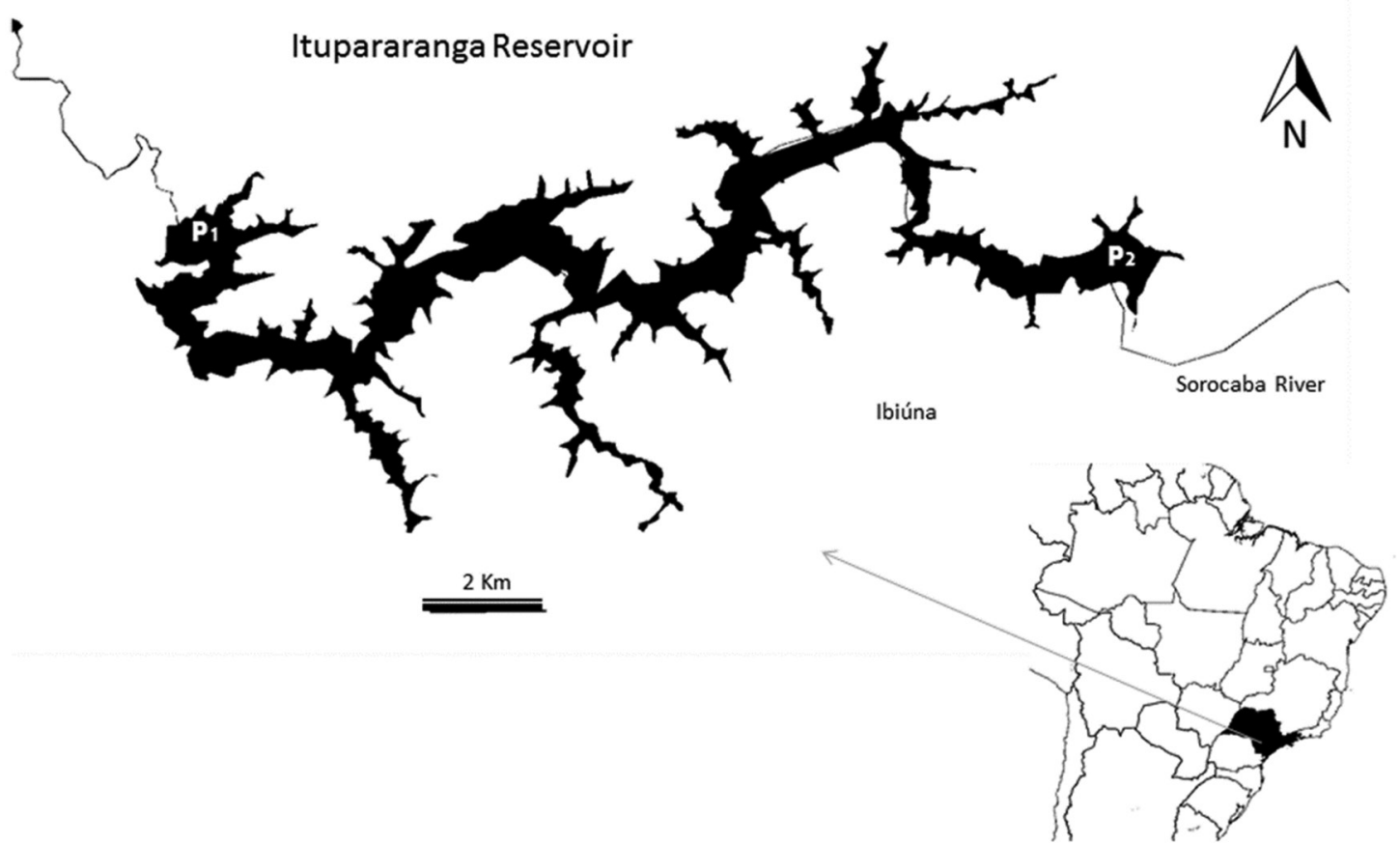

Figure 1. Location of Itupararanga Reservoir and sampling points. P1 $=$ dam and P2 = Entrance.

Table 1. Geographic coordinates of the sample points.

\begin{tabular}{lc}
\hline Sample Points & \multicolumn{1}{c}{ Geographic coordinates } \\
\hline Entrance & $23^{\circ} 37^{\prime} 3.8^{\prime \prime}$ S and $47^{\circ} 13^{\prime} 41.4^{\prime \prime} \mathrm{W}$ \\
Dam & $23^{\circ} 36^{\prime} 44.6^{\prime \prime} \mathrm{S}$ and $47^{\circ} 23^{\prime} 40.9^{\prime \prime} \mathrm{W}$ \\
\hline
\end{tabular}

\subsection{Microbial analysis}

First, the water samples $(1 \mathrm{~L})$ were passed through filter membranes of $0.45 \mu \mathrm{m}$ pore size (Milipore model HAQG047S3) and then through membranes of $0.22 \mu \mathrm{m}$ pore size (both of $0.47 \mathrm{~mm}$ diameter, Milipore model GSWP047S0). The DNA of the water was extracted from the membranes using a metagenomic DNA isolation kit for water (Epicentre laboratories), and from the sediments with the Ultraclean soil DNA isolation kit (Mobio laboratories), according to the manufacturer's instructions. The DNA concentrations were determined by measuring absorbance at $260 \mathrm{~nm}$ (A260). For pure DNA, the ratio of $A_{260}$ to $\mathrm{A}_{280}$ is between 1.8 and 1.9 (Wilhelm et al., 2003). The intact DNA was then confirmed by electrophoresis on a $1 \%$ agarose gel.

\subsection{Quantitative polymerase chain reaction analysis}

Quantitative real time PCR (qPCR) assays were used to measure the abundance of Bacteria and Archaea genes in the water column. To measure bacterial 16S rDNA, the primers P1 (CCT AGC GGA GGC AGC AG) and P2 (ATT ACC GCG
GCT GG) (Muyzer et al., 1993) were used and quantified with Platinum ${ }^{\circledR}$ Quantitative PCR super mix UDG (Invitrogen). Each reaction was performed in a volume of $25 \mu \mathrm{L}$ containing $1 \mu \mathrm{L}$ sample DNA, $0.25 \mu \mathrm{L}$ BSA and $1 \mu \mathrm{L}$ of each primer. The PCR cycling conditions were as follows: $3 \mathrm{~min}$ at $95^{\circ} \mathrm{C}, 35 \mathrm{cycles}$ of $30 \mathrm{sec}$ at $94^{\circ} \mathrm{C}, 30 \mathrm{sec}$ at $55^{\circ} \mathrm{C}$, $30 \mathrm{sec}$ at $72^{\circ} \mathrm{C}$ and a final extension at $72^{\circ} \mathrm{C}$ for 3 minutes.

For archaeal 165 rDNA, the primers 340F (CCC TAY GGG GTG CAS CAG) and 1000R (GAG ARG WRG TGC ATG GCC) (Gantner et al., 2011) were used and quantified with Platinum ${ }^{\circledR}$ Quantitative PCR super mix UDG (Invitrogen). Each reaction was performed in a volume of $25 \mu \mathrm{L}$ containing $1 \mu \mathrm{L}$ sample DNA, $0.25 \mu \mathrm{L}$ BSA, $50 \mathrm{pmol} \mathrm{MgCl}$ and $10 \mathrm{pmol}$ of each primer. The PCR cycling conditions were as follows: $2 \mathrm{~min}$ at $98^{\circ} \mathrm{C}, 35$ cycles of $30 \mathrm{sec}$ at $95^{\circ} \mathrm{C}, 30 \mathrm{sec}$ at $57^{\circ} \mathrm{C}, 90 \mathrm{sec}$ at $72^{\circ} \mathrm{C}$ and a final extension at $72^{\circ} \mathrm{C}$ for 7 minutes.

The copy number of $16 \mathrm{~S}$ rDNA in the samples was determined in duplicate and all PCR assays included a negative control containing no DNA to test for potential contamination. The abundance of target genes in each sample was estimated by parallel quantitative PCR assay of the dilutions of the standards and by comparing threshold cycles $(\mathrm{Ct})$, which is the cycle at which the fluorescence 
intensity surpasses the level at which amplification enters a logarithmic growth phase, obtained in each PCR run with DNA standards.

\subsection{Polymerase chain reaction/electrophoresis in gel of denaturant gradient}

The bacterial and archaeal communities from the water column were evaluated by Polymerase Chain Reaction and Denaturing Gradient Gel Electrophoresis (PCR-DGGE). The 16S rRNA genes from the Archaea and Bacteria domains were amplified using primers: $1100 \mathrm{~F}$ (with GC clamp) and 1400R (Kudo et al., 1997); 968 FGC and 1392R (Nielsen et al., 1999), respectively. Denaturing gradient gel electrophoresis (DGGE) was performed using the DcodeTMUniversal Mutation Detection System (Bio-Rad Laboratories, Hercules, CA, USA) in accordance with the manufacturer's instructions. The PCR products were electrophoresed in TAE buffer $(1 \mathrm{x})$ at $75 \mathrm{~V}$ for $16 \mathrm{~h}$ at $60^{\circ} \mathrm{C}$ on a polyacrylamide gel $(7.5 \%)$ containing a linear gradient of the denaturant from $45 \%$ to $65 \%$. The polyacrylamide gel was stained with ethidium bromide for $20 \mathrm{~min}$ and then visualized using an Eagle Eye TM III densitometer (Stratagene) with $254 \mathrm{~nm}$ UV exposures, coupled to a personal computer using Eagle Sight software.

\subsection{Statistical analysis}

Canonical Correspondence Analysis (CCA) was used to group the chemical and microbial properties. Correlation analysis of microbial abundances of samples from each site (dam and entrance) was performed. Pearson's similarity coefficient was calculated using BioNumerics ${ }^{\circledR}$ software, version 2.5. The Shannon-Wiener diversity index was calculated based on the intensity of the DGGE bands and on the height of the densitometric curve peaks, according to Abreu et al. (2010).

\section{Results and Discussion}

The water column was chemically and thermally stratified at both sampling sites. Surface water temperature at the dam and entrance was $24.4^{\circ} \mathrm{C}$ and 23.1 , respectively, decreasing to $22.7^{\circ} \mathrm{C}$ and $22.3^{\circ} \mathrm{C}$ at the bottom of the reservoir. Dissolved oxygen concentration decreased at the bottom of the reservoir, and while no anoxic zone was observed, hypoxia was identified (1.4 mg. $\mathrm{L}^{-1}$ and $2.5 \mathrm{mg} . \mathrm{L}^{-1}$, dam and entrance, respectively). The lower oxygen concentrations of the deeper layers are associated with the stratification of conditions (Salcher et al., 2011).
The center of the Itupararanga Reservoir is characterized by a stratification period in the summer and a homogeneous vertical profile during the winter. Contrastingly, the peripheral regions of the reservoir were stratified during both periods (Cunha \& Calijuri 2011a; Cunha et al., 2012; Miwa et al., 2011).

The nutrient concentration also varied along the water column. Organic and inorganic solids increased with depth at the entrance and decreased with depth at the dam. This profile is in agreement with the profile proposed by Thornton (1990), who divided a tropical reference reservoir into three zones. The first zone (riverine zone) occurs at the entrance of effluent and is characterized by greater water flow and a greater amount of allochthonous organic matter. The next zone (transitional zone) is characterized by intermediate conditions, and the last zone (lacustrine zone) is characterized by lower water flow and autochthonous organic matter.

Nitrogen, nitrate, nitrite, orthophosphate and phosphorus concentrations were higher in the entrance zone than at the dam (Table 2). According to Beghelli et al. (2014) these nutrients are received from tributary rivers.

The abundance of archaea and bacteria in the sediment was greater than in the water column (Figure 2), which may be associated with higher organic matter, nutrient concentrations and anoxic conditions of sediments.

The abundance of bacteria was greater in the sediment from entrance $\left(2.56 \times 10^{9}\right.$ cell. $\mathrm{g}^{-1}$ of sediment $)$ than from the dam $\left(6.09 \times 10^{8}\right.$ cells. $\mathrm{g}^{-1}$ of sediment) probably due to the high nutrients available. Beghelli et al. (2012), however, classified the entrance point as eutrophic and the remainder of the reservoir as mesotrophic. Tšertova et al. (2013) observed a similar profile in the eutrophic Lake Vartsjarv situated in southern Estonia, finding by flow cytometry a great abundance of bacteria in the river $\left(1.6 \times 10^{9} . \mathrm{g}^{-1}\right.$ dry weight $)$ and middle sediments of the lake $\left(1.8 \times 10^{9}\right.$ cells. $\mathrm{g}^{-1}$ dry weight) and low abundance in the littoral zone (8.0 x $10^{7} \cdot \mathrm{g}^{-1}$ dry weight).

Maintinguer etal. (2011) found hydrogenotrophic bacteria such as bacillus and endospore producers of hydrogen in the Itupararanga sediment and quantified the acidogenic bacteria to a more probable number $\left(4.3 \times 10^{2} \mathrm{NMP}^{-\mathrm{mL}^{-1}}\right.$ equivalent to $3.3 \times 10^{5} \mathrm{gSTV}-1$ cells).

This longitudinal pattern, with a higher trophic status in the riverine zone of reservoirs where the inflow rivers are found, is expected due to the 
Table 2. Mean of environmental variables in entrance zone and dam of Itupararanga Reservoir.

\begin{tabular}{|c|c|c|c|c|c|c|c|c|}
\hline \multirow{2}{*}{ Variables } & \multicolumn{5}{|c|}{ Dam } & \multicolumn{3}{|c|}{ Entrance } \\
\hline & $0.0 \mathrm{~m}$ & $2.0 \mathrm{~m}$ & $4.0 \mathrm{~m}$ & $10.0 \mathrm{~m}$ & $15.5 \mathrm{~m}$ & $0.0 \mathrm{~m}$ & $4.0 \mathrm{~m}$ & $8.0 \mathrm{~m}$ \\
\hline Temperature $\left({ }^{\circ} \mathrm{C}\right)$ & 24.39 & 24.26 & 24.16 & 23.34 & 22.7 & 23.14 & 22.62 & 22.28 \\
\hline $\mathrm{pH}$ & 7.34 & 7.18 & 7.09 & 6.15 & 6.45 & 6.92 & 6.42 & 6.33 \\
\hline Dissolved oxygen (mg. $\left.\mathrm{L}^{-1}\right)$ & 8.29 & 8.65 & 8.3 & 5.6 & 1.4 & 5.65 & 3.6 & 2.5 \\
\hline Conductivity $\left(\mu \mathrm{S} . \mathrm{cm}^{-1}\right)$ & 67 & 66 & 69 & 55 & 98 & 96 & 100 & 101 \\
\hline Total susp. solids (mg.L-1) & 5.7 & 4.65 & 5.25 & 3.1 & 1.75 & 5.9 & 6.8 & 8.65 \\
\hline Organic susp. solids (mg. $\left.\mathrm{L}^{-1}\right)$ & 1.7 & 1 & 2.25 & 1.25 & 0.45 & 2.8 & 3.85 & 5.5 \\
\hline Inorganic susp. solids (mg. $\left.\mathrm{L}^{-1}\right)$ & 4 & 3.65 & 3 & 1.85 & 1.3 & 3.1 & 2.95 & 3.15 \\
\hline Alkalinity $\left(\mathrm{mgCaCO}_{3} \cdot \mathrm{L}^{-1}\right)$ & 0.94 & 1.17 & 1.23 & 2.67 & 2.11 & 2.4 & 2.18 & 2.22 \\
\hline Orthophosphate $\left(\mu \mathrm{g} \cdot \mathrm{L}^{-1}\right)$ & 0.0022 & 0.0028 & 0.0025 & 0.0024 & 0.0026 & 0.006 & 0.0071 & 0.0078 \\
\hline Nitrate $\left(\mathrm{mg} \cdot \mathrm{L}^{-1}\right)$ & 0.35 & 0.39 & 0.4 & 0.39 & 0.39 & 0.61 & 0.57 & 0.61 \\
\hline Nitrite $\left(\mathrm{mg} \cdot \mathrm{L}^{-1}\right)$ & 0.66 & 0.52 & 0.565 & 0.58 & 0.64 & 4.63 & 4.05 & 6.55 \\
\hline Ammonia $\left(\mathrm{mg} \cdot \mathrm{L}^{1}\right)$ & 5.4 & 5.2 & 4.2 & 25.6 & 51.04 & 4.37 & 3.67 & 10.9 \\
\hline Dissolved Phosphorus (mg. $\left.\mathrm{L}^{-1}\right)$ & 0.37 & 0.53 & 0.43 & 0.51 & 0.57 & 1.06 & 1.27 & 1.73 \\
\hline Nitrogen Kjeldahl (mg. $\left.\mathrm{L}^{-1}\right)$ & 0.599 & 0.571 & 0.586 & 0.265 & 0.223 & 0.432 & 0.432 & 0.655 \\
\hline Chlorophyll $\left(\mu \mathrm{g} \cdot \mathrm{L}^{-1}\right)$ & 0.28 & 0.32 & 0.417 & 0.261 & 0.272 & 0.346 & 0.342 & 0.267 \\
\hline
\end{tabular}
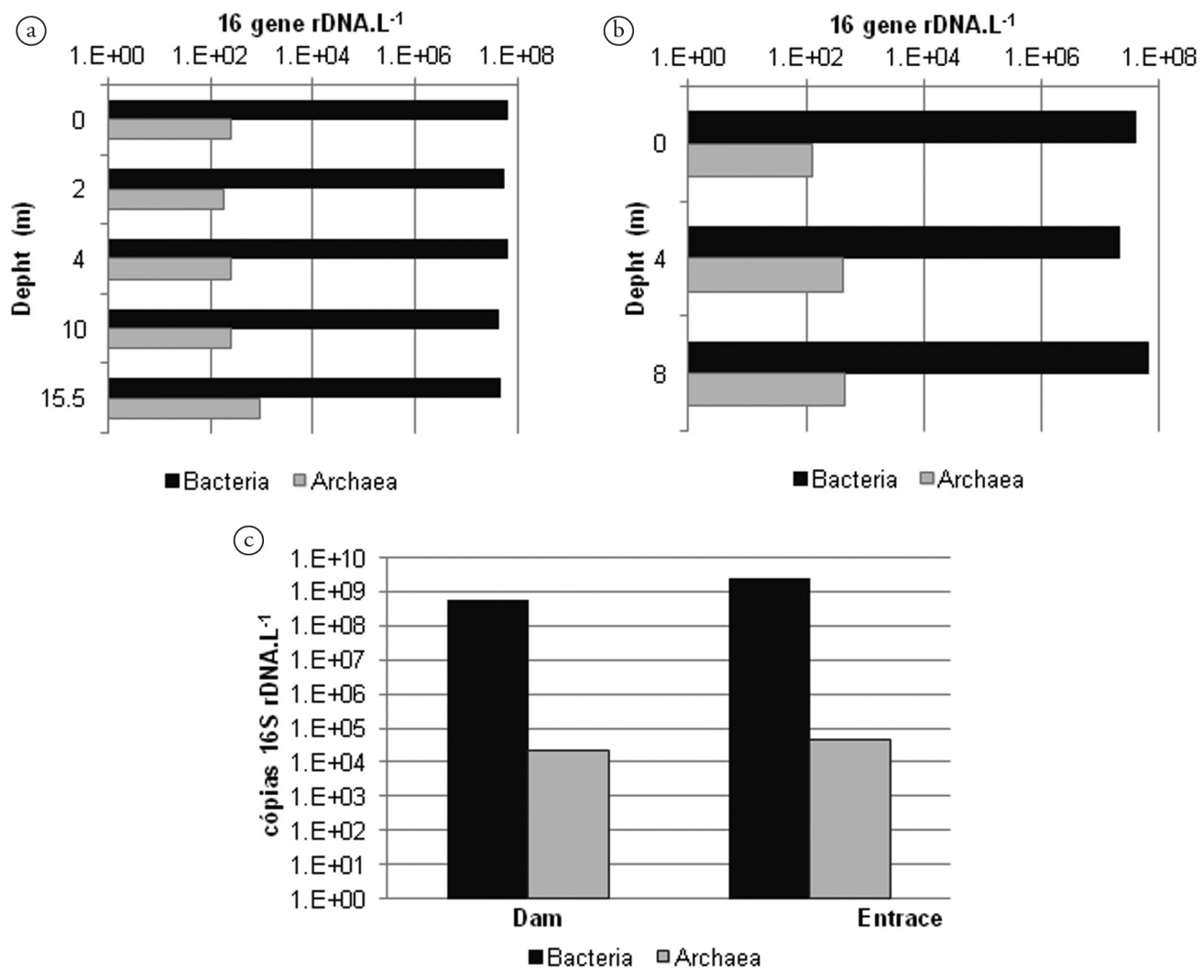

Figure 2. Relative abundance of Archaea and Bacteria community into the water column from (a) Dam, (b) Entrance and (c) Sediment of Itupararanga Reservoir.

reduction of flow and increased sedimentation (Nogueira et al., 1999; Thornton 1990). The higher density of Bacteria and Archaea in the sediment of this region can be an expected pattern in other reservoirs.

Bacteria were more abundant than archaea in both the water and sediment samples, most probably due to the fact that the metabolic plasticity of the bacterial communities is generalist, while archaeal communities are specialist and more adapted to stress conditions (Smeti et al., 2013).

The DGGE profiles for the archaeal and bacterial communities from the entrance and dam are shown in Figure 3. The archaeal communities 

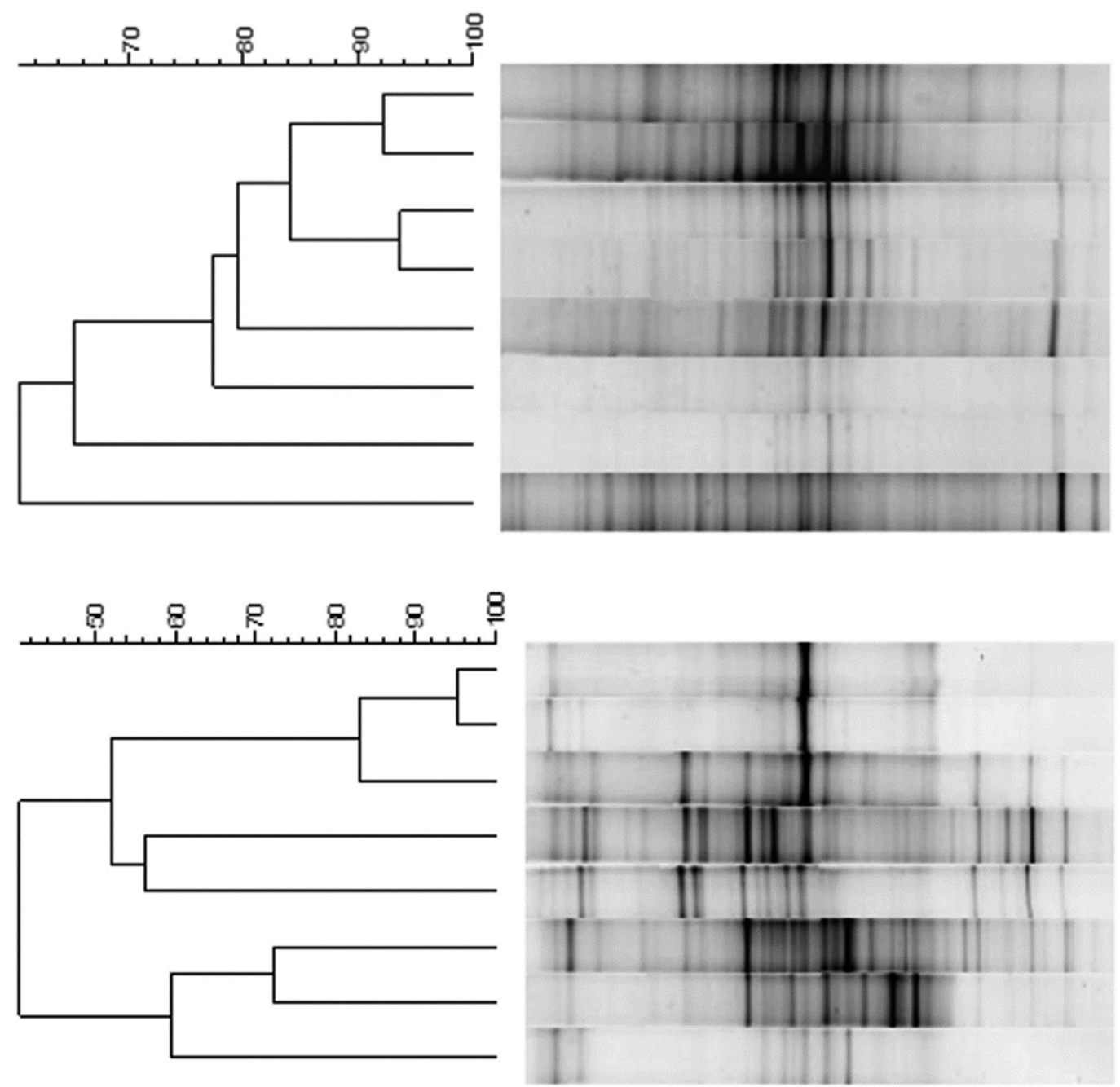

Figure 3. DGGE profile for Archaea (a) and Bacteria (b) Domain. Entrance E1 $=0 \mathrm{~m}$; E2 $=4.0 \mathrm{~m}$ and E3 $=8.0 \mathrm{~m}$; Dam D1 $=0 \mathrm{~m}, \mathrm{D} 2=2.0 \mathrm{~m}, \mathrm{D} 3=4.0 \mathrm{~m}, \mathrm{D} 4=10.0 \mathrm{~m}$ and D5 $15.5 \mathrm{~m}$.

were separated into two groups according to the sampled region (entrance and dam). On the other hand, lower variability was observed for the bacterial than the archaeal communities.

Major similarities were observed for the archaeal communities along the water column and along the reservoir. The similarity between the archaeal communities from the surface and the bottom was $60 \%$ and $94 \%$ at the entrance and at the dam, respectively, indicating that the environmental changes had more influence on the distribution of archaeal communities at the entrance than at the dam.

The greater similarity between the archaeal communities from the surface and the bottom at the dam (94\%) than at the entrance $(60 \%)$ was probably due to the greater stability in the dam region than at the entrance, despite the thermic and oxygenic stratification.
The similarity between the archaeal communities of the entrance and the dam was $78 \%$. In this sense, the archaeal community was distributed homogenously in the Itupararanga Reservoir.

On the other hand, the bacterial similarities between the surface and bottom were $42 \%$ and $52 \%$ at the dam and entrance, respectively, indicating that the chemical and thermal stratification of the water column had an important influence on the bacterial community.

The microbial diversity established from the DGGE profiles was measured with the Shannon diversity index $(\mathrm{H})$. At the entrance point $(\mathrm{P} 1)$ the diversity increased from the surface to the bottom (Table 3).

The archaeal diversity increased from the surface to the bottom at the entrance ( 1.47 to 2.50 ) and dam points (1.61 to 3.95 ). The same profile was observed for bacterial diversity at the dam 
(1.80 and 2.40, surface and bottom respectively) and entrance (1.53 and 2.62 surface and bottom, respectively). On the bottom of the reservoir low dissolved oxygen concentration was observed indicating that microbial diversity probably increased with the anoxic condition.

The results of Canonical Correspondence analysis highlighted the relationship between the variables responsible for spatial heterogeneity and microbial density and diversity. The archaeal diversity was influenced by profundity, as it increased along the water column, indicating anaerobe metabolism. On the other hand, bacterial diversity was influenced by dissolved oxygen in the Itupararanga Reservoir (Figure 4).

Table 3. Shannon diversity index $(\mathrm{H})$ for archaea and bacteria domains along the water column, from D1 (surface.) to D5 (deep) next to Dam, from E1 (surface.) to E3 (deep) in the Entrance zone.

\begin{tabular}{ccc}
\hline Sample & Archaea & Bacteria \\
\hline D1 & 1.61 & 1.80 \\
D2 & 3.06 & 2.84 \\
D3 & 2.44 & 2.54 \\
D4 & 3.64 & 2.78 \\
D5 & 3.95 & 2.49 \\
E1 & 1.47 & 1.53 \\
E2 & 2.25 & 1.54 \\
E3 & 2.50 & 2.62 \\
\hline
\end{tabular}

The archaeal density was related to ammonia, indicating that this metabolism has an important role in the Itupararanga Reservoir. Liu et al. (2011), in a study on the Dongjiang River, observed a higher archaeal density of Ammonia Oxidizing Archaea (AOA) than Ammonia Oxidizing Bacteria (AOB), and found that the AOA was more abundant than $\mathrm{AOB}$ at the lowest ammonia concentration, indicating that this nutrient is limiting.

On the other hand, bacterial density was related to chlorophyll and organic solids, indicating that autotrophic metabolism is predominant in bacterial communities from Itupararanga reservoir. The dominance of the cyanobacteria Cylindrospermopsis raciborskii (Wolozynska) Seenayya and Suba Raju in the Itupararanga Reservoir has been observed in different studies (Cunha \& Calijuri, 2011a, b), indicating that this community has an important role in the aquatic structure of the Itupararanga Reservoir.

Several studies (Ammar et al., 2014; Antunes et al., 2015) have indicated that C. raciborskii have a preference for ammonia as a nitrogen source, and therefore the study of the relationship between the nitrogen metabolism of bacteria and archaea and the dominance of C. raciborskii needs to be better understood.

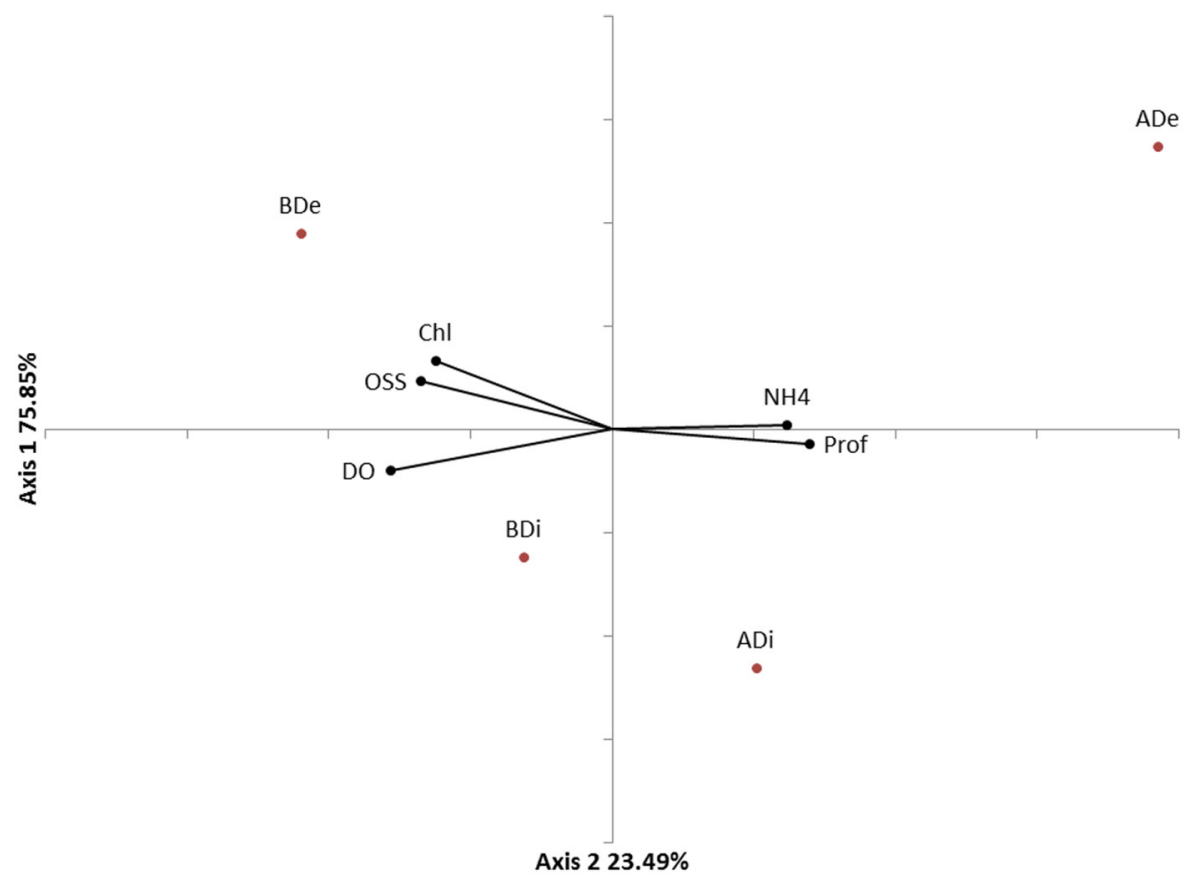

Figure 4. Correspondence Canonical Analysis (CCA) between environmental- Chlorophyll (Chl), Organics suspended solids (OSS), dissolved oxygen (DO), Profundity (Prof) and ammonia (NH4) and biological variables- Archaeal density (ADe) Bacterial density (BDe), Archaeal diversity (ADi) and Bacterial diversity (BDi) from Itupararanga Reservoir, SP, Brazil. 


\section{Conclusions}

The distribution of archaeal communities in the dam region was little influenced by environmental variation, as $94 \%$ of similarity was observed between the archaeal communities from the surface and the bottom. At the entrance the archaeal community was more influenced by the environmental changes in the water column than at the dam region, as the similarity between surface and bottom was $60 \%$.

A lower similarity was also observed between the bacterial communities from the surface and bottom at the entrance $(52 \%)$ and dam region (42\%), indicating that the bacterial communities were more influenced by environmental variation than archaeal communities.

The archaeal and bacterial diversities increased with profundity and the microbial abundance of both domains were greater in sediments, indicating that the characteristics at the bottom were more favorable to the development of microbial groups.

The bacterial abundance from the sediment of the entrance was greater than that of the dam, probably due to the nutrient input in the entrance region, which favors microbial abundance. Moreover, the bacterial abundance was greater than the archaeal abundance in all samples, probably due to the higher metabolic plasticity of the bacterial communities.

The diversity and density of the archaeal community were related to profundity and ammonia, respectively. This is probably due to the anaerobic conditions at the bottom, which favor anaerobic metabolism, and the fact that many archaea observed in aquatic environments are oxidizing ammonia.

Bacterial diversity and density in turn were related to dissolved oxygen, chlorophyll and solids, respectively, indicating the influence of autotrophic metabolism on the dominance of cyanobacteria in this reservoir.

The archaeal communities from the Itupararanga Reservoir were related to mineralization while the bacterial communities were related to the autotrophic metabolism.

Despite the fact that the present study used a small sample, the results encourage more research, mainly into the role of prokaryotic plankton in the nitrogen cycle in reservoirs and their interaction with the predominance of cyanobacteria.

\section{Acknowledgements}

We would like to thank CAPES (the Center for Improvement of Higher Education Personnel) and FAPESP (Process n ${ }^{\circ}$ 2008/55636-9) (São Paulo
Research Foundation) for funding this study. James J. Roper reviewed and corrected the English.

\section{References}

AbreU, A.A., ALVES, J.I., PEREIRA, M.A., KARAKASHEV, D., ALVES, M.M. and ANGELIDAKI, I. Engineered heat treated methanogenic granules: a promising biotechnological approach for extreme thermophilic biohydrogen production. Bioresource Technology, 2010, 101(24), 9577-9586. http://dx.doi.org/10.1016/j. biortech.2010.07.070. PMid:20709532.

ADAMCZUK, M., MIECZAN, T., NAWROT, D. and RECHULICZ, J. Indirect effect of environmental factors on interactions between microbial and classical food webs in freshwater ecosystems. Annales de Limnologie, 2015, 51(1), 49-58. http://dx.doi. org/10.1051/limn/2014032.

AMMAR, M., COMTE, K., CHI TRAN, T.D. and BOUR, M.E. Initial growth phases of two bloom-forming cyanobacteria (Cylindrospermopsis raciborskii and Planktothrix agardhii) in monocultures and mixed cultures depending on light and nutrient conditions. Annales de Limnologie, 2014, 50(3), 231-240. http://dx.doi.org/10.1051/limn/2014096.

ANTUNES, J.T., LEÃO, P.N. and VASCONCELOS, V.M. Cylindrospermopsis raciborskii: review of the distribution, phylogeography, and ecophysiology of a global invasive species. Frontiers in Microbiology, 2015, 6, 473. http://dx.doi.org/10.3389/ fmicb.2015.00473. PMid:26042108.

BEGHELLI, F.G., DOS SANTOS, A.C.A., URSOGUimARÃES, M.V. and CALIJURI, M.C. Relationship between space distribution of the benthic macroinvertebrates community and trophic state in a Neotropical reservoir (Itupararanga, Brazil). Biota Neotropica, 2012, 12(4), 114-124. http:// dx.doi.org/10.1590/S1676-06032012000400012.

BEGHELLI, F.G.S., DOS SANTOS, A.C.A., URSO-GUIMARÃES, M.V. and CALIJURI, M.D.C. Spatial and temporal heterogeneity in a subtropical reservoir and their effects over the benthic macroinvertebrate community. Acta Limnologica Brasiliensia, 2014, 26(3), 306-317.

BOWMAN, J.P. and MCCUAIG, R.D. Biodiversity, community structural shifts, and biogeography of prokaryotes within Antarctic continental shelf sediment. Applied and Environmental Microbiology, 2003, 69(5), 2463-2483. http://dx.doi.org/10.1128/ AEM.69.5.2463-2483.2003. PMid:12732511.

CARDOSO, A.M., VIEIRA, R.P., PARANHOS, R., CLEMENTINO, M.M., ALBANO, R.M. and MARTINS, O.B. Hunting for extremophiles in Rio de Janeiro. Frontiers in Microbiology, 2011, 2, 100. PMid:21747804. 
CUNHA, D.G.F. and CALIJURI, M.C. Limiting factors for phytoplankton growth in subtropical reservoirs: the effect of light and nutrient availability in different longitudinal compartments. Lake and Reservoir Management, 2011a, 27(2), 162-172. http://dx.doi. org/10.1080/07438141.2011.574974.

CUNHA, D.G.F. and CALIJURI, M.D. Seasonal variation of phytoplankton functional groups in the arms of a tropical reservoir with multiple uses (SP, Brazil). Acta Botanica Brasílica, 2011b, 25(4), 822-831. http://dx.doi.org/10.1590/S010233062011000400009.

CUNHA, D.G.F., OGURA, A.P. and CALIJURI, M.D.C. Nutrient reference concentrations and trophic state boundaries in subtropical reservoirs. Water Science and Technology, 2012, 65(8), 14611467. http://dx.doi.org/10.2166/wst.2012.035. PMid:22466594.

CURY, J.C., ARAUJO, F.V., COELHO-SOUZA, S.A., PEIXOTO, R.S., OLIVEIRA, J.A.L., SANTOS, H.F., DÁVILA, A.M.R. and ROSADO, A.S. Microbial diversity of a Brazilian Coastal Region influenced by an upwelling system and anthropogenic activity. PLoS One, 2011, 6(1), e16553. http:// dx.doi.org/10.1371/journal.pone.0016553. PMid:21304582.

DOLAN, J.R. An introduction to the biogeography of aquatic microbes. Aquatic Microbial Ecology, 2005, 41(1), 39-48. http://dx.doi.org/10.3354/ ame041039.

EATON, A.D., FRANSON, M.A.H., ASSOCIATION, A.P.H., ASSOCIATION, A.W.W., and FEDERATION, W.E. Standard methods for the examination of water \& wastewater. Washington: American Public Health Association, 2005, 1200 p.

FERRERA, I., SEBASTIAN, M., ACINAS, S.G. and GASOL, J.M. Prokaryotic functional gene diversity in the sunlit ocean: stumbling in the dark. Current Opinion in Microbiology, 2015, 25, 33-39. http://dx.doi.org/10.1016/j.mib.2015.03.007. PMid:25863027.

FRANCIS, C.A., ROBERTS, K.J., BEMAN, J.M., SANTORO, A.E. and OAKLEY, B.B. Ubiquity and diversity of ammonia-oxidizing archaea in water columns and sediments of the ocean. Proceedings of the National Academy of Sciences of the United States of America, 2005, 102(41), 14683-14688. http://dx.doi.org/10.1073/pnas.0506625102. PMid:16186488.

GANTNER, S., ANDERSSON, A.F., ALONSOSÁEZ, L. and BERTILSSON, S. Novel primers for $16 \mathrm{~S}$ rRNA-based archaeal community analyses in environmental samples. Journal of Microbiological Methods, 2011, 84(1), 12-18. http://dx.doi.org/10.1016/j.mimet.2010.10.001. PMid:20940022.
GASC, C., RIBIÈRE, C., PARISOT, N., BEUGNOT, R., DEFOIS, C., PETIT-BIDERRE, C., BOUCHER, D., PEYRETAILlADE, E. and PEYRET, P. Capturing prokaryotic dark matter genomes. Research in Microbiology, 2015, 166(10), 1-17. http://dx.doi.org/10.1016/j.resmic.2015.06.001. PMid:26100932.

GRAÇAS, D.A., MIRANDA, P.R., BARAÚNA, R.A., MCCULLOCH, J.A., GHILARDI JUNIOR, R., SCHNEIDER, M.P.C. and SILVA, A. Microbial diversity of an anoxic zone of a hydroelectric power station Reservoir in Brazilian Amazonia. Microbial Ecology, 2011, 62(4), 853-861. http://dx.doi. org/10.1007/s00248-011-9906-8. PMid:21755290.

GROSSART, H.-P. Ecological consequences of bacterioplankton lifestyles: changes in concepts are needed. Environmental Microbiology Reports, 2010, 2(6), 706-714. http://dx.doi.org/10.1111/j.17582229.2010.00179.x. PMid:23766274.

KUDO, Y., NAKAJIMA, T., MIYAKI, T. and OYAIZU, H. Methanogen flora of paddy soils in japan. FEMS Microbiology Ecology, 1997, 22, 39-48.

LIU, Z., HUANG, S., SUN, G., XU, Z. and XU, M. Diversity and abundance of ammoniaoxidizing archaea in the Dongjiang River, China. Microbiological Research, 2011, 166(5), 337-345. http://dx.doi.org/10.1016/j.micres.2010.08.002. PMid:20869216.

LLIRÓS, M., INCEOĞLU, Ö., GARCÍA-ARMISEN, T., ANZIL, A., LEPORCQ, B., PIGNEUR, L.M., VIROUX, L., DARCHAMBEAU, F., DESCY, J.P. and SERVAIS, P. Bacterial community composition in three freshwater reservoirs of different alkalinity and trophic status. PLoS One, 2014, 9(12), e116145. http://dx.doi.org/10.1371/journal.pone.0116145. PMid:25541975.

MAINTINGUER, S.I., LAZARO, C.Z., SAKAMOTO, I. and VARESCHE, M.B.A. Biological Hydrogen production from environmental sample in tropical countries. HOLOS Environment, 2011, 11(1), 26.

MIWA, A.C.P., BOTTINO, F., DOS SANTOS, A.C.A. and CALIJURI, M.C. Limnologia do Reservatório de Itupararanga. In S. BEU, A.C.A. DOS SANTOS and S.P. CASALI, eds. Biodiversidade na APA Itupararanga. Sorocaba: SMA/FF, 2011, pp. 65-71.

MUYZER, G., DE WAAL, E.C. and UITTERLINDEN, A.G. Profiling of complex microbial populations by denaturing gradient gel electrophoresis analysis of polymerase chain reaction-amplified genes coding for 16S rRNA. Applied and Environmental Microbiology, 1993, 59(3), 695-700. PMid:7683183.

NAKAYAMA, C.R., KUHN, E., ARAÚJO, A.C.V., ALVALÁ, P.C., FERREIRA, W.J., VAZOLLER, R.F. and PELLIZARI, V.H. Revealing archaeal diversity patterns and methane fluxes in Admiralty Bay, King George Island, and their association to Brazilian Antarctic Station activities. Deep-sea Research. Part II, 
Topical Studies in Oceanography, 2011, 58(1-2), 128138. http://dx.doi.org/10.1016/j.dsr2.2010.10.013.

NIELSEN, A.T., LIU, W.T., FILIPE, C., GRADY JUNIOR, L., MOLIN, S. and STAHL, D.A. Identification of a novel group of bacteria in sludge from a deteriorated biological phosphorus removal reactor. Applied and Environmental Microbiology, 1999, 65(3), 1251-1258. PMid:10049891.

NOGUEIRA, M.G., HENRY, R. and MARICATTO, F.E. Spatial and temporal heterogeneity in the Jurumirim Reservoir, São Paulo, Brazil. Lakes and Reservoirs: Research and Management, 1999, 4(34), 107-120. http://dx.doi.org/10.1046/j.14401770.1999.00086.x.

OLEYNIK, G.N., YURISHINETS, V.I. and STAROSILA, Y.V. Bacterioplankton and bacteriobenthos as biological indicators of the aquatic ecosystems. State, 2011, 47(2), 37-48.

PEDRAZZI, F.J.D.M., CONCEIÇÃO, F.T.D., SARDINHA, D.D.S., MOSCHINI-CARLOS, V. and POMPEO, M. Spatial and temporal quality of water in the Itupararanga Reservoir, Alto Sorocaba Basin (SP), Brazil. Journal of Water Resource and Protection, 2013, 5(1), 8.

SALCHER, M.M., PERNTHALER, J., FRATER, N. and $\mathrm{POSCH}, \mathrm{T}$. Vertical and longitudinal distribution patterns of different bacterioplankton populations in a canyon-shaped, deep prealpine lake. Limnology and Oceanography, 2011, 56(6), 20272039. http://dx.doi.org/10.4319/lo.2011.56.6.2027.

SARMENTO, H. New paradigms in tropical limnology: the importance of the microbial food web. Hydrobiologia, 2012, 686(1), 1-14. http://dx.doi. org/10.1007/s10750-012-1011-6.

SIMS, A., HORTON, J., GAJARAJ, S., MCINTOSH, S., MILES, R.J., MUELLER, R., REED, R. and HU, Z. Temporal and spatial distributions of ammoniaoxidizing archaea and bacteria and their ratio as an indicator of oligotrophic conditions in natural wetlands. Water Research, 2012, 46(13), 4121-4129. http://dx.doi.org/10.1016/j.watres.2012.05.007. PMid:22673339.

SMETI, E., KORMAS, K.A. and SPATHARIS, S. A non-phylogenetic alpha diversity approach on prokaryotic community structure in aquatic systems. Ecological Indicators, 2013, 29, 361-366. http:// dx.doi.org/10.1016/j.ecolind.2013.01.027.
THOMPSON, F.L., BRUCE, T., GONZALEZ, A., CARdoso, A., Clementino, M., COSTAGLIOLA, M., HOZBOR, C., OTERO, E., PICCINI, C., PERESSUTTI, S., SCHMIEDER, R., EDWARDS, R., SMITH, M., TAKIYAMA, L.R., VIEIRA, R., PARANHOS, R. and ARTIGAS, L.F. Coastal bacterioplankton community diversity along a latitudinal gradient in Latin America by means of V6 tag pyrosequencing. Archives of Microbiology, 2011, 193(2), 105-114. http://dx.doi. org/10.1007/s00203-010-0644-y. PMid:21076816.

THORNTON, K.W. Perspectives on reservoir limnology. In K.W. THORNTON, B.L. KIMMEL and F.E. PAYNE, eds. Reservoir limnology: ecological perspectives. New York: Wiley-Interscience, 1990, pp. 1-13.

TŠERTOVA, N., KISAND, A., BATY, F. and KISAND, V. Homogeneous microbial diversity in the upper sediment layers of a shallow lake. Aquatic Microbial Ecology, 2013, 70(1), 77-85. http://dx.doi. org/10.3354/ame01647.

TURQUE, A.S., BATISTA, D., SILVEIRA, C.B., CARDOSO, A.M., VIEIRA, R.P., MORAES, F.C., CLEMENTINO, M.M., ALBANO, R.M., PARANHOS, R., MARTINS, O.B. and MURICY, G. Environmental shaping of sponge associated archaeal communities. PLoS One, 2010, 5(12), e15774. http://dx.doi.org/10.1371/journal. pone.0015774. PMid:21209889.

WILHELM, J., PINGOUD, A. and HAHN, M. Real-time PCR-based method for the estimation of genome sizes. Nucleic Acids Research, 2003, 31(10), e56-e56. http://dx.doi.org/10.1093/nar/gng056. PMid:12736322.

WILLIAMS, T.J. and CAVICCHIOLI, R. Marine metaproteomics: deciphering the microbial metabolic food web. Trends in Microbiology, 2014, 22(5), 248260. http://dx.doi.org/10.1016/j.tim.2014.03.004. PMid:24731505.

ZEGLIN, L. Stream microbial diversity responds to environmental changes: review and synthesis of existing research. Frontiers in Microbiology, 2015, 6, 6. http://dx.doi.org/10.3389/fmicb.2015.00454. PMid:26042102.

Received: 15 December 2015 Accepted: 16 March 2016 